\title{
PREDICTING PATHWAYS OF GRIT AMONG UNDERGRADUATE STUDENTS
}

\author{
Hayat Muhammad", Summiya Ahmad* \\ \& Nosheen Iffat Zohra*
}

\begin{abstract}
The present research examines how the presence of psychological wellbeing, resilience, hope, subjective happiness, and meaning in life can increase psychological grit in 482 undergraduate students. To test this model, positive psychology factors are used as a predictor of psychological grit. Positive psychology factors influence the passion and perseverance of the undergraduate students of the university to achieve their short-and longterm goals. To gather information from the participants, we used the grit scale, Ryff psychological wellness scale, brief resilience scale, purpose in life scale, subjective happiness scale, and hope scale. The variables in the studies were calculated using correlation and regression analysis. Psychological well-being and resilience were found to be important predictors of psychological grit in the study. The findings of the study have implications for counsellors, planners, and politicians who must consider all of the variables that predict and increase grit in university students.
\end{abstract}

Keywords: Psychological Grit, Well-Being, Resilience, Hope, Undergraduate Students

\section{Introduction}

Fully functioning individuals as those who are more directed towards their true selves, those will strive in achieving their life goals because they are capable enough to remain in touch with their emotions. Those who focus on themselves to attain meaningful goals and convince and pursue helping behavior and values will bring harmony within their existence and beings (Vainio \& Daukantaite, 2016). Intrinsic motivation, which is the core principle of development and movement, leads to positive growth. Every

\footnotetext{
"Department of Psychology, University of Peshawar.
} 
person is intrinsically motivated to develop, and this propensity is expressed under favorable conditions or is hindered and suffocated by the external environment, which blocks and hinders the organismic process. (Rogers, 1961;194).

Maintaining and enhancing growth potential which will ultimately achieve the actualization stage, is possible through the subconscious and biologically driven process. It will guide individuals to evaluate new life experiences (Ryan, \& Deci, 2000; Emmons, 2003; Sheldon, Ryan, Deci, \& Kasser, 2004; Deci, \&Ryan, 2000).

Goal-directed life is essential, which is a prerequisite to achieve peace and prosperity in life. In attaining long-term goals, one has to face countless distractions in daily life, which hinders moving towards achieving goals. During the current era of social networking, the youth of the world in general and Pakistan, in particular, are spending hours and hours using these gadgets without focusing on their academic and other creative and constructive activities: (Facebook, Twitter, etc.). During this scenario, it is essential to examine positive psychological factors which can bring drastic change to focus youth (students) on life goals and make them more passionate and perseverant.

Students who start their formal education from school and ultimately reach university for higher education. It is the generation, who will take hold of the position which will vacate by the just upper-tier age. In this way, one day, lead and drive the vehicle of the country affairs. Taking responsibility to bring harmony and tranquility depends on building a high level of passion and perseverance among students. At any time in the initial span of life of students, they have unique needs, challenges and at the same time have potential and strengths, which are the result of social, intrapersonal, and personal challenges. In the whole process of achieving life goals, students face so many stressors which can cause and put them at high risk of suicidal ideation, depression symptoms, distress and other issues related to mental health (CFDCP, 2001; Roberts, Roberts \& Chen, 1997; Choi, Meininger, \& Roberts, 2006; Eaton et al., 2006; Goldston et al., 2008; Wagstaff \& Polo, 2012).

There is a rapid change in the modern world despite which some individuals remain consistent in attaining their life goals, and these potential efforts help them achieve success (Beechler, \& Woodward, 2009; Greene, 2006). These individuals have intrinsic motivation, which makes them able to take some practical steps and actions to face and overcome all the hardships and challenges they will encounter (Ryan, Deci, \& Kessar, 2004; Deci, 1975).

Positive psychology, according to Seligman (2002), plays an important role and provides a useful mechanism for understanding students' mental health, job growth, and academic achievements. Researchers and practitioners should also use a positive psychology paradigm to consider the 
productivity of the factors that will contribute to critical outcomes and devise action plans to achieve specific targeted factors that will aid academic performance and mental health. Positive psychology develops and targets methods to improve and strengthen health, positive emotion, and happiness (Seligman, 2002). Dispositional characteristics that will push and drive individuals to get success while achieving life goals have recently been conceptualized as "grit" (Duckworth, Peterson, Mathews \& Kelly, 2007).

Sustained self-control, motivation, and perseverance are needed to achieve and focus on the personally essential and long-term goal of grit (Duckworth, Peterson, Mathews, \& Kelly, 2007). Grit is a construct made up of two elements: effort persistence and interest consistency (Duckworth \& Seligman, 2005). Grit is associated with specific characteristics of conscientiousness, such as perseverance and diligence (Duckworth, Tsukayama, \& Kirby, 2013). Grit, like conscientiousness, has some predictive capacity in predicting academic success, according to Rimfeld, Kovas, Dale, and Plomin (2016). Other research has found a clear connection between grit and high life-cause achievements outside of education (Abuhassan \& Bates, 2015).

According to Duckworth et al. (2011), gritters purposefully spent more time on a spelling test, thus improving their efficiency. Self-control is more closely linked to daily progress. Grit, on the other hand, is closely linked to outstanding and extraordinary accomplishment, which can take decades or even a lifetime to achieve (Duckworth \& Gross, 2014). In a militarydiscipline summer Programme, researchers discovered that students' grit is related to academic achievement and retention (Robertson-Kraft \& Duckworth, 2014; Duckworth et al., 2007). (e.g. Eskreis-Winkler et al., 2014).

According to Salles, Cohen, and Mueller (2014), there is a close connection between grit and psychological well-being. One recent study looked at the connection between psychological well-being and grit, which is influenced by one's perception of the world as manageable, coherent, and resourceful, as well as how meaningful one perceives life to be.

Adapting well while facing adversity, tragedy, threats, trauma, or significant stress sources is considered the process of resilience. Optimistic view-appraising situations without distorting them also include thinking and planning about changes that are part of life to occur in the whole life span. It is an idea of giving a positive response to challenges, failure, and adversity. Being resilient individuals doesn't mean that no one will experience difficulty or distress (Southwick \& Charney, 2012).

The ability to "bounce back" quickly and effectively from traumatic situations is a sign of psychological resilience, according to the theoretical paradigm (Carver, 1998). The relationship between resilience and grit as a separate paradigm has received very little analysis. According to Duckworth et al., 2007; Duckworth and Quinn, 2007, resilience is a component of grit 
(2009). Grit and toughness are closely related in terms of understanding different facets of human actions and behavior in the face of difficulty in achieving life goals (Almeida, 2016; Cassidy, 2015). The presence of resilience has been linked to undergraduates' academic persistence when coping with mental health issues (Hartley, 2016). According to study, there is a clear connection between psychological well-being and resilience. Abolghasemi and Varaniyab (2010) described resilience as a predictor of life satisfaction.

Hope is the guiding force of creation. Existence is impossible without hope. Hope was once used interchangeably with abstract visions, wishes, and other sentiments. Snyder (1994) and Snyder et al. (1994) provided definitions of hope (1998). Hope is described as "a positive motivation of effective agency and pathways organized interactively, consisting of pathways thought that operates through various means to achieve desired goals," according to them.

In the psychological literature, happiness has been defined in various ways, but most definitions agree that happiness is a psychological state of joy, wellbeing, and contentment (Otake, Shimai, Tanaka-Matumi, Otsui, \& Fredrickson, 2006; Lyubmomirsky, 2001). The happiness concept is increasingly popular in psychology and found to be a significant and vital part of life and human experience (Lyubomirsky, 2001). Literature has shown that behaviour and mental health are closely related to wellbeing and happiness (Chaplin, 2006; Liem \& Dillon, 2010; Valois, Paxton, Zullig \& Huebbner, 2006). Adolescent's life satisfaction is significantly related to their reported positive wellbeing (McCullough, Huebbner, \& Laughlin, 2000).

According to Duckworth and Quinn (2007), there is a connection between happiness and academic achievement. Duckworth and Quinn (2007) found a connection between academic achievement and happiness. Chen and $\mathrm{Lu}$ (2009) looked at class size, overall school satisfaction, general happiness, and academic achievement among Taiwanese students in 11th grade. Vela and Castro (2014) investigated the relationship between happiness, spirituality, and meaning in life among Latino college students and discovered a strong correlation between the existence of meaning in life and subjective happiness.

Meaning in life is one of the psychological virtues and a significant contributor to positive psychology, according to Steger, Frazier, Oishi, and Kaler (2006). (Seligman, Ernst, Gillham, Reivich, \& Linkins, 2009). The importance of meaning in one's life is linked to one's personal happiness (Steger \& Kashdan, 2007). People who seek meaning in their lives aren't always happy or free of sadness, suffering, or despair. Life's nature isn't a new topic for debate and discussion (Kernes \& Kunnier, 2008). The search for meaning and the presences of meaning are two facets of existence meaning proposed by Steger and Shin (2010). Finding a sense of meaning in 
life has both positive and negative mental health effects, according to research (Moomal, 1999; Steger, Frezier, Oishi, \& Kaler, 2006; Zika \& Chamberlain, 1992).

The psychological literature is increasingly pointing to a connection between mental health, academic achievement, and personal fulfilment (Brassai, Piko, \& Steger, 2011; Steger \& Shin, 2010; Vela, Castro et al., 2014). The majority of the researchers discovered a connection between meaning in life and happiness; however, it is also critical to investigate the link between meaning in life and psychological grit in students. The following hypotheses are part of this research:

- There would be a relationship between grit, resilience, psychological wellbeing, hope, happiness, and meaning in life.

- Positive psychological factors are more likely to predict the high level of psychological grit in undergraduate students.

\section{Method}

\section{CONCEPTUAL MODEL OF THE STUDY}

Figure 1

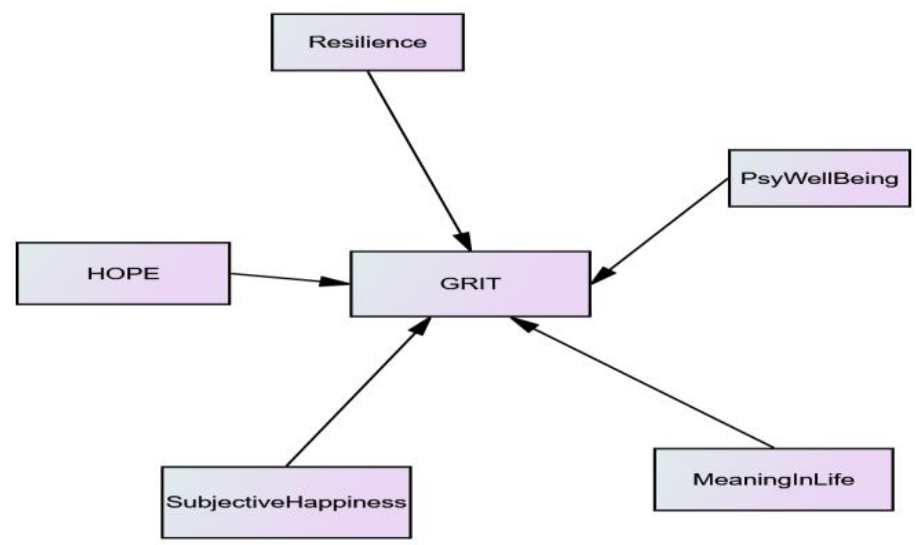

\section{Participants}

The population of this study was undergraduate students taken from Faculty of Social Sciences (Department of Psychology, Sociology, Economics, and social work), the University of Peshawar (UOP). In the present study, 482 undergraduate students were taken from the undergraduate program of the fall semester $\left(1^{\text {st }}\right.$ semester, $3^{\text {rd }}$ semester, $5^{\text {th }}$ semester, and $7^{\text {th }}$ semester $($ men $=50.6 \% \&$ women $=49.4 \%)$ mean age range 
20.25 years $(S D=3.42)$, who enrolled in the undergraduate scheme of study. The purposive sampling technique was employed to collect data.

The age range of 20.25. In the present study, students who enrolled in the undergraduate scheme of the study were taken as a sample of the studythe sample of the study taken from undergraduate students of the fall semester.

\section{Measures}

\section{Psychological Grit Scale}

The Grit Short Scale was created by Duckworth and Quinn (2009). It's a tool for evaluating long-term dedication and perseverance. On a 5-point Likert scale, this scale consists of eight statements that range from very much like me (5) to not at all like me (5). (1). The higher the grit scale score, the greater the perceived psychological grit. Reliability coefficients range from.78 to.82 (Duckworth et al., 2011). The current study found that evidence of the grit scale's reliability with university undergraduate students was adequate, with a score of 81 .

\section{Ryff Psychological Well-Being Scale (RyffPWBS)}

The Ryff Psychological Well-Being Scale was developed by Ryff (1989). This is a non-reversed scale, with 44 elements ranging from 1 to 6 on a 6-point Likert scale, with 1 indicating strong disagreement and 6 indicating strong agreement. Ryff (1989c) used the 120-item version to test a six-factor model based on theory in a sample of young, middle-aged, and older adults. Internal accuracy ranged from 0.86 to 0.93 . Six variables' intercorrelation ranged from 0.32 to 0.76 , raising questions about the factors' distinctness.

\section{Brief Resilience Scale (BRS)}

The Brief Resilience Scale (BRS) was developed by Smith, Dalen, Wiggins, Tooley, Christopher, and Bernard in 2008. It's a six-item scale that measures resilience, or the ability to bounce back from adversity. The BRS employs a five-point Liker scale ranging from Strongly Disagree (1) to Strongly Agree (5). (5). (\#5) A higher BRS score suggests a more tenacious respondent. The BRS is a one-factor scale with just one factor. Cronbach's alpha reliability for the BRS ranges from 0.80 to 0.91 . The BRS had a reliability of 0.81 in the current study.

\section{Hope Scale}

The Hope Scale was created by Snyder et al. (1991) to measure respondents' attitudes toward priorities and goals. Agency and Pathways are the two subscales of the Hope Scale. The Hope Scale consists of eight statements that are scored on an 8-point Likert scale ranging from strongly 
agreed (8) to strongly disagreed (8). (1). On the Hope scale, the reliability coefficients range from 0.77 to 0.81 . The current study's Cronbach's alpha was 0.84 .

\section{Subjective Happiness Scale (SHS)}

The 4-item Likert-type scale, developed by Lyubomirsky and Lepper (1999). In a validation analysis, Lyubomirsky and Lepper (1999) discovered an appropriate reliability index, with alpha coefficients ranging from 0.80 to 0.94 in 14 separate samples $(\mathrm{N}=2.732)$.

\section{Meaning in Life Questionnaire (MLQ)}

The Meaning of Life Questionnaire was developed by Steger et al (2006). On a seven-point Likert scale, the MLQ has ten arguments that range from Absolutely True (7) to Absolutely Untrue (7). (1). The reliability coefficients on the Presence of Meaning in Life subscale range from 0.70 to 0.93, while those on the Search for Meaning in Life subscale range from 0.87 to 0.90 (Park et al., 2010; Sunn \& O'Brien, 2009; Vela, Lerma, et al., 2014). Cronbach's alpha reliability in this analysis was 0.90.

\section{Procedure}

Several steps were completed prior to data collection. The first move was to seek permission from the Institutional Heads. Students were approached in the second phase using a purposive sampling technique. In the third step, students were informed that their participation in the research survey is entirely voluntary, and that no credit would be awarded as a result of their participation. Questionnaires were handed out during training, and they took between 15 to 20 minutes to complete. Scores from all data (Questionnaires) were compiled after data collection was completed and fed into a data management Programme (SPSS AMOS) to be computed.

\section{Research Design}

In the current research, survey research method was used,

\section{Results}

Data were analyzed by using correlation and multiple regression to conclude assumptions.

Preliminary bivariate correlations were assessed among the variables. Association among criterion and predictor variables was given low with all predictor variables in a prudent model. 


\section{Primary Analysis}

Multiple Regression analyses were used to see the relationship between predictor and criterion variables (Table 1)

\section{Table 1: Evaluation Table of Bivariate Correlation among Predictor Variables}

\begin{tabular}{|c|c|c|c|c|c|c|}
\hline Variable & 1 & 2 & 3 & 4 & 5 & 6 \\
\hline Grit & -- & $.626^{* *}$ & $.498 * *$ & $-.077^{*}$ & -.011 & .056 \\
\hline PsyWellBeing & & - & $.586^{* *}$ & $-.080 *$ & -.004 & -.011 \\
\hline Resilience & & & - & -.047 & -.034 & -.012 \\
\hline Hope & & & & - & $.077 *$ & -.059 \\
\hline Subjective Happiness & & & & & - & .014 \\
\hline Meaning in Life & & & & & & - \\
\hline
\end{tabular}

Regression analysis was conducted to investigate the variables predicting psychological grit (see Table No. 2). Statistically significant model is yielded by regression analysis, $\mathrm{F}(5,479)=69.81, \mathrm{p}<.001, \mathrm{R}_{2}=.42$, indicative of a large effect size in which $42 \%$ of the change is accounted by predictors among the scores estimating psychological grit. Score which are associated with the participants psychological well-being within the model measured a very significant predictive relationship $\left(B=.18, p<.0001, \mathrm{sr}_{2}=\right.$ $.50)$, which is the indication of medium effect size. Findings suggests that $24 \%$ of change in participants' scores on psychological grit $(B=.47, p<$ $\left..0001, \mathrm{sr}_{2}=.20\right)$ is attributed to the student's resilience indicative of a medium effect size. Nonsignificant findings revealed that scores related to hope $\left(B=-.01, p<.50, \mathrm{sr}_{2}=-.023\right)$, subjective happiness $(B=-.003, p<.96$, $\left.\mathrm{sr}_{2}=-.002\right)$ and meaning in life $\left(B=.065, p<.07, \mathrm{sr}_{2}=.062\right)$.

Table 2: Summary Table of Variables Predicting Psychological Grit

\begin{tabular}{|l|c|c|c|c|c|c|c|}
\hline \multicolumn{1}{|c|}{ Variables } & $\mathrm{B}$ & SEB & $\beta$ & $\mathrm{t}$ & Sig & $\mathrm{F}$ & $\mathrm{R}^{2}$ \\
\hline Grit & & & & & & 69.819 & .423 \\
\hline Psywell-Being & .189 & .016 & .508 & 11.798 & .000 & & \\
\hline Resilience & .472 & .102 & .200 & 1.645 & .000 & & \\
\hline Hope & -.017 & .026 & -.023 & -.667 & .505 & & \\
\hline Subjective Happiness & -.003 & .067 & -.002 & -.046 & .963 & & \\
\hline Meaning in Life & .065 & .036 & .062 & 1.709 & .074 & & \\
\hline
\end{tabular}




\section{Path Model of Regression (Predictors and Criterion Variables)}

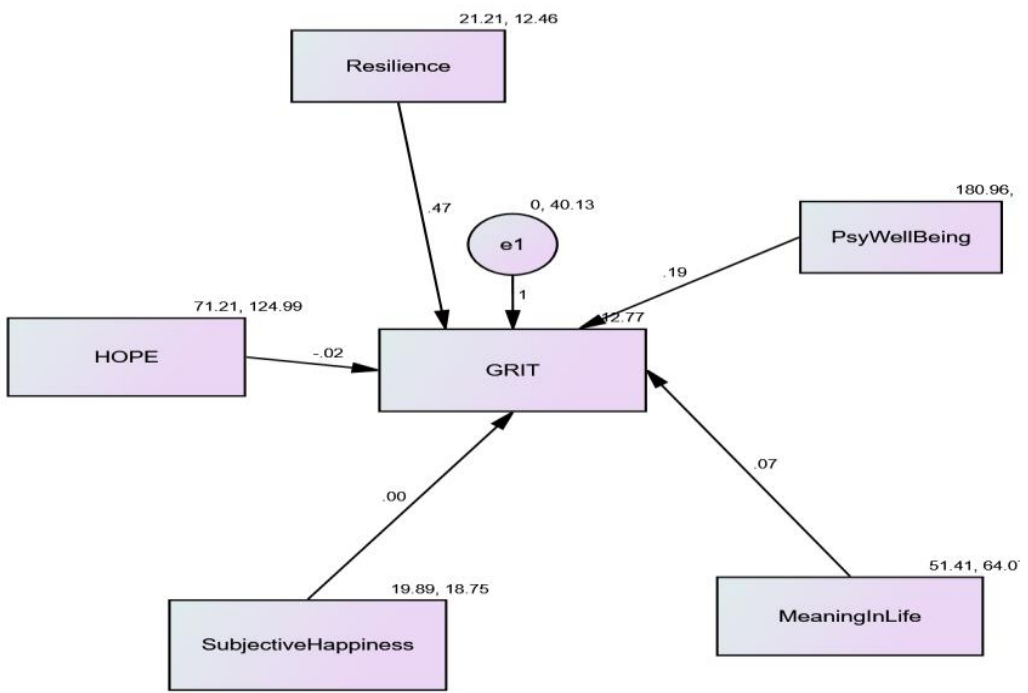

Figure 2. Shows comparative analysis in men and women students through independent t-test (see table 3).

It was hypothesized that there will be no significant differences between men and women students about predicting and criterion variables. Result yielded that there is difference between male and female students on scores of Psychological Wellbeing $(\mathrm{M}=177.57 \& \mathrm{M}=184.42, p=.001)$ and similarly in resilience, result shows female students are more resilient than male students $(\mathrm{M}=20.83$ and $\mathrm{M}=21.58, p=.02)$.

Table 3: Means, Standard Deviations and t-value of the Male and Female Students $(\mathrm{N}=482)$

\begin{tabular}{|l|c|c|c|c|c|c|c|c|c|}
\hline Variables & \multicolumn{2}{|c|}{$\begin{array}{c}\text { Male } \\
(\mathrm{n}=244)\end{array}$} & \multicolumn{2}{c|}{$\begin{array}{c}\text { Female } \\
(\mathrm{n}=238)\end{array}$} & \multicolumn{4}{c|}{} & \multicolumn{2}{c|}{$95 \%$ CI } & $\begin{array}{c}\text { Cohen's } \\
\mathrm{d}\end{array}$ \\
\hline & $\mathrm{M}$ & $\mathrm{S} . \mathrm{D}$ & $\mathrm{M}$ & S.D & $\mathrm{t}$ & $\mathrm{p}$ & LL & UL & \\
\hline Grit & 59.19 & 8.066 & 58.97 & 8.644 & .286 & .775 & -1.278 & 1.713 & 0.025 \\
\hline $\begin{array}{l}\text { Psy Well } \\
\text { Being }\end{array}$ & 177.57 & 22.931 & 184.42 & 21.343 & -3.391 & .001 & -10.813 & -2.879 & 0.039 \\
\hline Resilience & 20.83 & 3.644 & 21.58 & 3.381 & -2.334 & .020 & -1.377 & -.118 & 0.284 \\
\hline Hope & 71.61 & 11.041 & 70.79 & 11.351 & .796 & .426 & -1.191 & 2.816 & 0.072 \\
\hline $\begin{array}{l}\text { Subjective } \\
\text { Happiness }\end{array}$ & 19.89 & 3.858 & 19.89 & 4.780 & .017 & .986 & -.769 & .783 & 0.001 \\
\hline $\begin{array}{l}\text { Meaning in } \\
\text { Life }\end{array}$ & 51.36 & 9.069 & 51.46 & 6.780 & -.133 & .894 & -1.533 & 1.338 & 0.012 \\
\hline
\end{tabular}

$p<.001$ 


\section{Discussion}

This study findings contribute to extending our understanding of the association between positive psychological and psychological grit among undergraduate students at a university level in a multidimensional manner. The current study results have the strength to devise strategies for intervention to improve the psychological wellbeing and resilience among students, directly impacting the improvement of psychological grit. In the findings of this study, it is extracted that psychological wellbeing and resilience have a substantial impact and are predictors of psychological grit. In light of our results, it can be suggested that as we increase the students' psychological wellbeing, their resilience will also increase the student's level of passion and perseverance.

Students' engagement occurs when students are psychologically engaged in learning linked with psychological wellbeing (Lamborn, Newmann \& Wehlage, 1992). Students can be involved despite facing challenges and obstacles; students will apply in their work, remain persistent, and even feel proud of accomplishing their assigned tasks (Bomia et .al, 1997). Psychological wellbeing will increase the stamina of students. According to Duckworht (2013), grit is the disposition based on the passion and perseverance required to pursue a long-term goal sustained over time, emphasizing increasing stamina.

The current study's findings reveal a strong positive relationship between grit and psychological well-being, as well as a strong positive relationship between grit and resilience among undergraduate students. The hedonistic component of health is the pursuit of pleasure and a good life (Diener, 1984). It is considered in previous studies that grit is related to numbers of success factors and goals achievement, which shows that grit plays a vital role in creating meaningful motivation of goals achievement (Duckworth et al., 2007; Reed et al., 2013; Maddi, Matthews, Kelly, Villarreal, \& White, 2012). Sheldon et al. (2010) explored that wellbeing will be enhanced with the persistent engagement with the goals, which satisfies one's need for 6-months. Persistence with satisfying goals will be conducive to wellbeing.

The principle of "existential courage," described as the ability to react to and remain flexible and courageous in the face of life's challenges, is absent from the existing definition of grit, according to Maddi et al. (2013). The findings of Tiittanen M. (2014) suggested that grit is comprised of such courage, which is required to bring harmony in life. It is recommended that gritty people face life's challenges flexibly rather than remaining stiff and rigid, strengthening and ensuring wellbeing. Research findings of the current study revealed that psychological wellbeing and resilience directly impact grit among undergraduate students. There is a connection between grit and psychological well-being, as well as between grit and resilience. Increased 
psychological well-being and endurance can improve students' grit. These findings are consistent with Skinner, Pitzer, and Brule (2014), which mentioned that engagement in work and motivational resilience are positively correlated.

Hope, subjective satisfaction, and meaning in life are also thought to affect students' grit, according to the current research. Grit will increase as hope, subjective satisfaction, and life meaning increase. The study's findings indicate that there is no correlation between students' grit and their hope, which contradicts research conducted by other researchers in a different cultural context. It's possible that these observations are due to the cultural background.

According to Vela, et al. (2017), hope is the most robust predicting variable in predicting the presence of psychological grit in college students, which suggests that the increase in hope will increase the level of students' grit. The belief in pursuing and attaining the desired objectives is considered a hope (Feldman \& Dreher, 2012), along with the confidence to make struggle and progress in achieving those goals (Snyder et al., 1999).

Psychological well-being and resilience, as well as hope, subjective satisfaction, and life meaning, were all considered predictors and components of the conceptual model (framework) for understanding the meaning of students' grit. None of these factors, including hope, subjective satisfaction, and life sense, predicted students' grit among undergraduates. Vela, Smith, et al. (2017) proved that hope and students grit have a close relationship, and an increase in hope means an increase in students' grit. Findings of present research indicated that hope, happiness and meaning in life have no relationship with students' grit.

There could be many reasons for these unexpected results, which shows no relationship between happiness, hope, meaning in life, and students' grit. First, keeping in view the country's cultural context like Pakistshow general and Khyber Pakhtunkhwa in particular, the situation in the previous 20 years where the general public is prone to terrorism and bomb blasts made them resilient and psychologically adjusted. Due to those reasons, results show that psychological wellbeing and resilience have a close relationship with students' grit. Second, psychological wellbeing and resilience are more important for students' grit than undergraduate students. Third, the sample was selected only from Khyber Pakhtunkhwa, which may also be the reason for not including students from other regions having different lifestyles within the same country. Researchers from this region have advocated for expanding the study's scope to include a greater sample size in order to investigate the moderating and mediating relationships between positive psychology and people in other occupations as well as people living in terrorism-affected areas. 


\section{Limitation}

Every research has its limitations. In the present study, self-reporting of the students related to their perception of positive psychology variables might hinder understanding the variables like happiness, meaning in life, and hope prone to several biases. Further, the present research relied on the undergraduate university population, which brought homogeneity, though, to generalize the results, the sample could have been collected from the community.

\section{Conclusion and Research Implication}

The primary goal of this study was to determine the role of positive psychological factors in the development of psychological grit in undergraduate students. Based on the findings of this study, it can be concluded that psychological wellbeing and resilience highly predicted psychological grit and that grit, psychological wellbeing, and resilience have a close relationship. Increased psychological well-being and endurance in students can lead to greater perseverance and enthusiasm for long-term goals. The results indicate that focusing on enhancing psychological health and endurance, as well as growing students' grit, should be a priority when developing and launching intervention plans and services for students. The results also showed no significant connection between hope, subjective satisfaction, and life meaning and student grit, which may be attributed to the university's undergraduate students' diverse cultural backgrounds.

\section{Ethics Statement and Informed Consent}

There is no institutional review board of the University of Peshawar, Khyber Pakhtunkhwa, Pakistan, and this research study is a joint venture of colleagues. Built a conceptual model and done an empirical study. Written consent was obtained from the participant, and verbal consent was obtained from the head of the departments for the collection of data.

\section{Conflict of Interest Statement}

It is submitted that there is no conflict of interest among authors or with any other body.

\section{Funding}

It is submitted that there is no funding agency to support this research study. 


\section{References}

Abolghasemi, A., \&Varaniyab, S.T. (2010). Resilience and perceived stress: predictors of life satisfaction in the students of success and failure. Procedia-Social and Behavioral Sciences, 5, 748-752.

Abuhassàn, A, \& Bates, T.C. (2015) Grit: Distinguishing effortful persistence from conscientiousness Journal of Individual Differences, 36(4), 205-214. https://doi org/10 1027/1614-0001/a000175

Almeida, D.J. (2016). Understanding grit in the context of higher education. In M.B. Paulsen 31(Ed.), Higher education: Handbook of theory and research (pp. 559-609). Switzerland: Springer International Publishing.

Barresi, J. (1999). On becoming a person. Philosophical Psychology, 12(1), 79-98.

Bomia, L., Beluzo, L., Demeester, D., Elander, K., Johnson, M., \& Sheldon, B. (1997). The impact of teaching strategies on intrinsic motivation. Champaign, IL: ERIC Clearinghouse on Elementary and Early Childhood Education.

Brassai, L., Piko, B.F., \& Steger, M.F. (2011). Meaning in life: Is it a protective factor for adolescents' psychological health? International Journal of Behavioral Medicine, 18, 44-51. https://doi:10.1007/s12529010-9089-6.

Carver, C.S. (1998). Resilience and thriving: Issues, models, and linkages. Journal of social issues, 54(2), 245-266.

Chaplin, T.M. (2006). Anger, happiness, and sadness: associations with depressive symptoms in late adolescence. Journal of Youth and Adolescence, 35(6), $977-986$.

Deci, E.L., \& Ryan, R.M. (1975). Intrinsic motivation. John Wiley \& Sons, Inc.

Deci, E.L., \& Ryan, R.M. (2000). The" what" and" why" of goal pursuits: Human needs and the self-determination of behaviour. Psychological Inquiry, 11(4), 227-268.

Diener, E., Larsen, R.J., \& Emmons, R.A. (1984). Person Situation interactions: Choice of situations and congruence response models. Journal of personality and social psychology, 47(3), 580.

Duckworth, A.L., \& Seligman, M.E.P. (2005). Self-discipline outdoes IQ in predicting academic performance of adolescents Psychological Science, 16(12), 939-944. Doi org/10 1111/j 1467-9280 200501641

Duckworth, A.L., \& Eskreis-Winkler, L. (2013). True grit. The observer, 26(4), 1-3.

Duckworth, A.L., \& Quinn, P.D. (2009). Development and validation of the Short Grit Scale (Grit-S). Journal of Personality Assessment, 91, 166174. 
Duckworth, A.L., \& Seligman, M.E.P. (2006). Self-discipline gives girls the edge: Gender in self-discipline, grades, and achievement test scores. Journal of Educational Psychology, 98(1), 198-208.

Duckworth, A.L., \& Quinn, P.D. (2009). Development and validation of the short grit scale (Grit-S). Journal of Personality Assessment. 91, 166174 Doi: 10.1080/ 00223890802634290

Duckworth, A.L., Kirby, T.A., Tsukayama, E., Berstein, H., \& Ericsson, K. A. (2011). Deliberate practice spells success why grittier competitors triumph at the national spelling bee. Social psychological and personality science, 2(2), 174-181.

Duckworth, A.L., Peterson, C., Matthews, M.D., \& Kelly, D.R. (2007). Grit: Perseverance and passion for long-term goals Journal of Personality and Social Psychology 92(6), 1087-101. Doi org/10 1037/0022-3514 92 61087.

Duckworth, A.L., Peterson, C., Matthews, M.D., \& Kelly, D.R. (2007). Grit: perseverance and passion for long-term goals. Journal of Personality and Social Psychology, 92, 1087-1101. Doi: 10.1037/00223514.92.6.1087.

Duckworth, A.L., Tsukayama, E., \& Kirby, T.A. (2013). Is it really selfcontrol? Examining the predictive power of the delay of gratification task. Personality \& Social Psychology Bulletin, 39(7), 843-55. Doi org/10 1177/0146167213482589.

Duckworth, A., \& Gross, J.J. (2014). Self-control and grit: Related but separable determinants of success. Current Directions in Psychological Science, 23(5), 319-325.

Duckworth, A.L., Kirby, T.A., Tsukayama, E., Berstein, H., \& Ericsson, K. A. (2011). Deliberate practice spells success why grittier competitors triumph at the national spelling bee. Social Psychological and Personality Science, 2(2), 174-181.

Eskreis-Winkler, Duckworth, A.L., Shulman, E.P., \& Beal, S. (2014). The grit effect: Predicting retention in the military, the workplace, school, and marriage. Frontiers in Psychology, 5, 1-29. doi:10.3389/fpsyg.2014.00036

Feldman, D.B., \& Dreher, D.E. (2012). Can hope be changed in 90 minutes? Testing the efficacy of a single-session goal-pursuit intervention for college students? Journal of Happiness Studies, 13, 745-759. doi:10.1007/s10902-011-9292-4

Feldman, D.B., Rand, K.L., \& Kahle-Wrobleski, K. (2009). Hope and goal attainment: Testing a basic prediction of hope theory. Journal of Social and Clinical Psychology, 28, 479-497.

George, L.S., \& Park, C.L. (2016). Meaning in life as comprehension, purpose, and mattering: Toward integration and new research questions. Review of General Psychology, 20, 205-220. 
Hartley, M.T. (2016). Investigating the relationship of resilience to academic persistence in college students with mental health issues. Rehabilitation Counseling Bulletin, 56, 240-250.

Hill, P.L., Burrow, A.L., \& Bronk, K.C. (2016). Persevering with positivity and purpose: An examination of purpose commitment and positive affect as predictors of grit. Journal of Happiness Studies, 17, 257-269.

Kernes, J.L. \& Kinder, R.T. (2008). Meaning in psychologists' personal and professional lives. Journal of Humanistic Psychology, 48(2), 196 - 220.

Kleiman, E.M., Adams, L.M., Kashdan, T.B., \& Riskind, J.H. (2013). Gratitude and grit indirectly reduce risk of suicidal ideations by enhancing meaning in life: Evidence for a mediated moderation model. Journal of Research in Personality, 47, 539-546.

Liem, J.H., Lustig, K. \& Dillon, C. (2010). Depressive symptoms and life satisfaction among emerging adults: A comparison of high school dropouts and graduates. Journal of Adult Development, 17,33-43.

Lyubormirsky, S. (2001). Why are some people happier than others? The role of cognitive and motivational processes in wellbeing. American Psychologist, 56(3), 239 - 249.

Maddi, S.R., Erwin, L.M., Carmody, C.L., Villarreal, B.J., White, M., \& Gundersen, K.K. (2013). Relationship of hardiness, grit, and emotional intelligence to internet addiction, excessive consumer spending, and gambling. The Journal of Positive Psychology, 8(2), 128-134.

Maddi, S.R., Matthews, M.D., Kelly, D.R., Villarreal, B., \& White, M. (2012). The role of hardiness and grit in predicting performance and retention of USMA cadets. Military Psychology, 24, 19-28.

Marques, S.C., Pais-Ribeiro, J.L., \& Lopez, S.J. (2011). The role of positive psychology constructs in predicting mental health and academic achievement in children and adolescents: A two-year longitudinal study. Journal of Happiness Studies, 12, 1049-1062. Doi:10.1007/s109020109244-4.

Marques, S.C., Pais-Ribeiro, J.L., \& Lopez, S.J. (2011). The role of positive psychology constructs in predicting mental health and academic achievement in children and adolescents: A two-year longitudinal study. Journal of Happiness Studies, 12, 1049-1062. doi:10.1007/s109020109244-4.

Mason, H.D. (2018). Grit and academic performance among first-year university students: A brief report. Journal of Psychology in Africa, 28(1), 66-68.

McCabe, K. \& Barnett, D. (2000). First comes work, then comes marriage: Future orientation among African American young adolescents. Family Relations, 49, 63-70.

McCuUough, G., Huebner, E.S. \& Laughlin, J.E. (2000). Life events, selfconcept, and adolescents' positive subjective wellbeing. Psychology in the Schools, 37(3) $281-290$. 
Moomal, Z. (1999). The relationship between meaning in life and mental wellbeing. South African Journal of Psychology, 29(1), 42 - 49.

Newman, F.M., Wehlage, G.G. \& Lamborn, S.D. (1992) The Significance and Sources of Student Engagement. In: Newman, F. M., Ed., Student Engagement and Achievement in American Secondary Schools. Teachers College Press, New York, 11-39.

Otake, K., Shimai, S., Tanaka-Matsumi, J., Otsui, K. \& Fredrickson, B. (2006). Happy people become happier through kindness: A counting kindnesses intervention. Journal of Happiness Studies, 7,361- 375.

Oyserman, D., Bybee, D. \& Terry, K. (2006). Possible selves and academic outcomes: How and when possible selves impel action. Journal of Personality and Social Psychology, 91(1), 188 - 204.

Reed, J., Pritschet, B.L., \& Cutton, D.M. (2013). Grit, conscientiousness, and the transtheoretical model of change for exercise behaviour. Journal of Health Psychology, 18(5), 612-619.

Rimfeld, K., Kovas, Y., Dale, P.S., \& Plomin, R. (2016). True grit and genetics: Predicting academic achievement from personality Journal of Personality and Social Psychology, 111(5), 780-789 Doi org/10 1037/pspp0000089.

Robertson-Kraft, C., \& Duckworth, A.L. (2014). True grit: Trait-level perseverance and passion for long-term goals predict effectiveness and retention among novice teachers. Teachers College Record, 116, 1-25.

Rogers, C.R. (1957). On becoming a person. In S. Doniger (Ed.). Houghton Mifflin Company. Boston.

Ryan, R.M., \& Deci, E.L. (2000). Self-determination theory and the facilitation of intrinsic motivation, social development, and wellbeing. American psychologist, 55(1), 68.

Ryff, C.D. (1989). Happiness is everything, or is it? Explorations on the meaning of psychological wellbeing. Journal of Personality and Social Psychology, 57(6), 1069.

Ryff, C.D. (2017). Eudemonic wellbeing, inequality, and health: Recent findings and future directions. International Review of Economy, 64, $159-178$.

Ryff, C.D. (2013). Eudemonic wellbeing and health: Mapping consequences of self-realization In Waterman, A.S. (Ed.). The best within us: Positive psychology perspectives on eudaimonia,77-98. Washington, DC US: American Psychological Association.

Salles, A., Cohen, G.L., \& Mueller, C.M. (2014). The relationship between grit and resident wellbeing. The American Journal of Surgery, 207(2), 251-254.

Seligman, M. (2011). Flourish: A new understanding of happiness, wellbeing and how to achieve them. Nicholas Brealey Publication. 
Seligman, M.E. (2002). Authentic happiness: Using the new positive psychology to realize your potential for lasting fulfilment. New York, NY: Free Press.

Seligman, M.E. (2011). Flourish. New York, NY: Simon \& Schuster.

Seligman, M.E.P. \& Csikszentmihalyi, M. (2000). Positive Psychology: An Introduction. American Psychologist, 55, 5-14.

Seligman, M.E., Ernst, R.M., Gillham, J., Reivich, K., \& Linkins, M. (2009). Positive education: Positive psychology and classroom interventions. Oxford Review of Education, 35, 293-311.

Seligman, M.E., Ernst, R.M., Gillham, J., Reivich, K., \& Linkins, M. (2009). Positive education: Positive psychology and classroom interventions. Oxford Review of Education, 35, 293-311.

Sheldon, K.M., Abad, N., Ferguson, Y., Gunz, A., Houser-Marko, L., Nichols, C.P., \& Lyubomirsky, S. (2010). Persistent pursuit of needsatisfying goals leads to increased happiness: A 6-months longitudinal experimental study. Motivation and Emotion, 34(1), 39- 48. Doi: 10.1007/s11031-009-9153-1.

Siddoway, R. (2013). Grit. The Rosen Publishing Group.

Singh, K., \& Jha, S.D. (2008). Positive and negative affect and grit as predictors of happiness and life satisfaction. Journal of the Indian Academy of Applied Psychology, 34(2), 40-45.

Singh, K., Junnakar, M., \& Mitra, S. (2018). Validation of Hindi translated scales on Grit, Resilience and Well-being. Journal of the Indian Academic of Applied Psychology, 44(1), 89-98.

Skinner, E.A., Pitzer, J.R. \& Brule, H.A. (2014). The role of emotion in engagement, coping and the development of motivational resilience. International Handbook of Emotions in Education. Taylor and Francis Group.

Snyder, C.R. (1994) The psychology of hope: You can get there from here. Simon and Schuster Publisher.

Snyder, C.R., Irving, L.M., \& Anderson, J.R. (1991). Hope and health. Handbook of social and clinical psychology: The Health Perspective, 162, 285-305.

Snyder, C.R., LaPointe, A.B., Crowson, J., Early, S. (1998). Preferences of high-and low-hope people for self-referential input. Cognition \& Emotion, 12(6), 807-823.

Snyder, C.R., Michael, S.T., \& Cheavens, J.S. (1999). Hope as a psychotherapeutic foundation of nonspecific factors, placebos, and expectancies. In Hubble, M.A., Duncan, B., \& Miller, S. (Eds.). Heart and soul of change (pp. 179-200). Washington, DC: American Psychological Association.

Southwick, S.M., \& Charney, D.S. (2012). The Science of Resilience: Implications for the Prevention and treatment of depression. Science, 338(6103), 79-82. 
Steger, M. \& Kashdan, T. (2007). Stability and specificity of meaning in life and life satisfaction over one year. Journal of Happiness Studies, 8, 161179.

Steger, M., \& Shin, J.Y. (2010). The relevance of the Meaning in Life Questionnaire to therapeutic practise: A look at initial evidence. The International Forum for Logotherapy, 33, 95- 104.

Steger, M., Frazier, P., Oishi, S. \& Kaler, M. (2006). The meaning in life questionnaire: assessing the presence of and search for meaning in life. Journal of Counseling Psychology, 53(1), 80 - 93.

Stone, A.A., Turkkman, J.S., Bachrach, C.A., Jobe, J.B., Kurtzman, H.S., \& Cain, V.S. (2002). The science of self-report: Implications for research and practice. Mahwah, NJ: Erlbaum

Tiittanen, M. (2014). Grit and Different Aspects of Well-being: Direct and indirect effects via the sense of coherence and authenticity. (Master's Thesis Spring). Lunds University, Sweden.

Vainio, M.M., \& Daukantaite, D. (2016). Grit and Different Aspects of Well-Being: Direct and Indirect Relationships via Sense of Coherence and Authenticity. Journal of Happiness Studies, 17(5), 2119-2147.

Valois, R.F., Paxton, R.J., Zullig, K.J. \& Huebner, E.S. (2006). Life satisfaction and violent behaviours among middle school students. Journal of Child and Family Studies, 15(6), 695 - 707.

Vela, J.C., Castro, V., Cavazos, L., Cavazos, M., \& Gonzalez, S.L. (2014). Understanding Latina/o students' meaning in life, spirituality, and subjective happiness. Journal of Hispanic Higher Education, 14, 171184. Doi:1177/1538192714544524

Vela, J.C., Ikonomopoulos, J., Lenz, A.S., Hinojosa, Y., \& Saldana, K. (2017). Evaluation of the Meaning in Life Questionnaire and Dispositional Hope Scale with Latino students. Journal of Humanistic Counseling, 56, 166-179. doi:10.1002/johc.12051.

Vela, J.C., Lu, M.-T. P., Lenz, A.S., \& Hinojosa, K. (2015). Positive psychology and familial factors as predictors of Latino students' psychological grit. Hispanic Journal of Behavioral Sciences, 37, 287303.

Vela, J.C., Smith, W.D., Whittenber, J.F., Guardila, R., \& Savage, M. (2018). Positive psychology factors as predictors of Latino college students' psychological grit. Journal of Multicultural Counseling \& Development, 46(1), 02-19. 